\title{
PENGARUH KOMPETENSI PEDAGOGIK DOSEN AKUNTANSI DAN PROFESIONALISME DOSEN AKUNTANSI TERHADAP MOTIVASI BELAJAR MAHASISWA AKUNTANSI \\ (Studi Tentang Persepsi Mahasiswa Akuntansi di Universitas Pamulang Tahun Akademik 2015/2016)
}

\author{
Yulyanah \\ Universitas Pamulang \\ annisayulyanah@yahoo.co.id
}

\begin{abstract}
The purpose of this study was to determine how to student's perception about the pedagogical competence of accounting lecturer in the learning process, whether there is significant influence between the pedagogic competence of accounting lecturer and professioalism of accounting lecturer with learning motivation accounting student at the Pamulang University in academic year 2015/2016. This research uses descriptive method that involved 169 respondent by using questionnaires. Analyzed using a statistical simple regression analysis (SPSS V.23). Result showed that the variables (pedagogical competence of accounting lecturer and professioalism of accounting lecturer) simultaneously positive effect on learning motivation.
\end{abstract}

Keywords: pedagogical competence, professionalism, learning motivation

\section{PENDAHULUAN}

Perguruan tinggi adalah salah satu tempat pendidikan yang menjadi sumber dan perkembangan ilmu pengetahuan. Ilmu pengetahuan itu sendiri menentukan tingkat kemajuan suatu bangsa. Hal tersebut tercermin dari digunakannya faktor tingkat pendidikan yang dimiliki penduduk suatu negara sebagai salah satu indikator utama kemajuan suatu bangsa.

Soewardjono (1999) dalam Hanum (2010: 2) menyatakan bahwa pemahaman akuntansi merupakan suatu kemampuan seseorang untuk mengenal dan mengerti tentang akuntansi. Tingkat pemahaman akuntansi ini dapat diukur dari nilai mata kuliah yang meliputi nilai pengantar akuntansi, akuntansi keuangan menengah, nilai akuntansi keuangan lanjutan, nilai pemeriksaan akuntansi (pengauditan), dan nilai teori akuntansi.

Dalam keseluruhan upaya pendidikan, kegiatan belajar mengajar (KBM) merupakan aktivitas yang paling penting, karena melalui proses inilah tujuan 
pendidikan akan tercapai dalam bentuk perubahan perilaku peserta didik. Untuk mewujudkan keberhasilan proses belajar mengajar, banyak faktor yang dapat menjadi penentu. Makmun (2007), mengemukakan setidaknya ada tiga unsur yang harus ada dalam proses belajar rmengajar yaitu (1) peserta didik (mahasiswa) dengan segala karakteristiknya untuk mengembangkan dirinya seoptimal mungkin melalui kegiatan belajar, (2) pengajar (dosen/guru) yang selalu mengusahakan terciptanya situasi yang tepat untuk belajar sehingga memungkinkan untuk terjadinya proses pengalaman belajar, dan (3) tujuan, yaitu sesuatu yang diharapkan setelah adanya kegiatan belajar.

Dosen merupakan salah satu komponen yang sangat berperan dalam proses pembelajaran, dan secara langsung mempengaruhi peningkatan kualitas belajar mahasiswa. Agar proses belajar dapat berjalan dengan baik maka kompetensi yang dimiliki dosen menjadi salah satu faktor yang dapat memotivasi mahasiswa untuk belajar. Diantara kompetensi yang perlu dimiliki dosen adalah kompetensi pedagogik dan profesionalisme dosen.

Jika kita melihat fenomena saat ini ada banyak mahasiswa yang melakukan tindak yang kurang bermanfaat bahkan merugikan dirinya dan lingkungannya. Hasil survei peneliti pada Prodi Akuntansi S1 di semester gasal 2015/2016 tercatat ada lebih dari 100 mahasiswa/i Univeritas Pamulang yang meremedial atau merevisi nilai di mata kuliah Pengantar Akuntansi 1, dikarenakan nilai yang kurang maksimal setelah proses perkuliahan berlangsung, rata-rata mahasiswa mendapatkan prestasi yang rendah serta merevisi kembali mata kuliah tersebut. Mahasiswa yang melakukan remedial ini tentunya belum memenuhi kriteria ketuntasan minimal (KKM) yang telah ditentukkan Universitas Pamulang. Karena yang digunakan adalah standar Kurikulum Berbasis Kompetensi (KBK), dimana kurikulum ini berorientasi pada pencapaian hasil (out-put oriented) yang dirumuskan dalam bentuk kompetensi. 


\section{TELAAH LITERATUR DAN PENGEMBANGAN HIPOTESIS}

\section{Tinjauan Teori}

\section{Teori Taxonomy Bloom}

"Taksonomi berasal dari bahasa Yunani taxis yang berarti pengaturan dan nomos yang berarti ilmu pengetahuan" (Muhammad Yaumi, 2013). "Taksonomi adalah sistem klasifikasi” (John W. Santrock, 2007). Taksonomi berarti klasifikasi berhierarki dari sesuatu atau prinsip yang mendasari klasifikasi atau juga dapat berarti ilmu yang mempelajari tentang klasifikasi. Istilah ini kemudian digunakan oleh Benjamin Samuel Bloom, seorang psikolog bidang pendidikan yang melakukan penelitian dan pengembangan mengenai kemampuan berpikir dalam proses pembelajaran.

\section{Teori Belajar Kognitif}

"Teori belajar kognitif merupakan teori belajar yang tidak hanya melibatkan hubungan antara stimulus dan respon" (Hamzah. B. Uno, 2010). Teori belajar ini lebih mementingkan proses belajar dari pada hasil belajar itu sendiri.

\section{Teori Etika}

Menurut Susanto (1992:42) dalam Hermawati (2007) etika atau dalam bahasa Inggris "ethics" adalah sebuah ilmu tentang kesusilaan yang memperhatikan atau mempertimbangkan tingkah laku manusia dalam pengambilan keputusan moral, etika mengarahkan atau menghubungkan penggunaan akal budi individual dengan obyektivitas untuk menentukan "kebenaran" atau "kesalahan" dan tingkah laku seseorang terhadap orang lain.

\section{Teori Motivasi}

\section{Teori Motivasi Kepuasan (Content Theory)}

1. Teori Hierarki Kebutuhan

2. Teori Tiga Motif Sosial 


\section{Teori Motivasi Proses (Process Theory)}

1. Teori Harapan

2. Teori penetapan tujuan (goal setting theory)

\section{Pengertian Kompetensi}

Menurut UU No. 14 tahun 2005 tentang Guru dan Dosen Pasal 1, Ayat 10, disebutkan "Kompetensi adalah seperangkat pengetahuan, ketrampilan, dan perilaku yang harus dimiliki, dihayati, dan dikuasai oleh guru atau dosen dalam melaksanakan tugas keprofesionalan”. pengetahuan dan keterampilan.

\section{Pedagogik}

Menurut Prof. Dr. J. Hoogveld (Belanda) pedagogik adalah ilmu yang mempelajari masalah membimbing anak kearah tujuan tertentu, yaitu supaya ia kelak mampu secara mandiri menyelesaikan tugas hidupnya. Menurut PP RI No.19 Tahun 2005 pasal 28 tentang standar nasional pendidikan, bahwa yang dimaksud kompetensi pedagogik adalah kemampuan mengelola pembelajaran peserta didik yang meliputi pemahaman terhadap peserta didik, perencanaan dan pelaksanaan pembelajaran, evaluasi hasil belajar, dan pengembangan peserta didik untuk mengaktualisasikan berbagai potensi yang dimilikinya.

\section{Profesionalisme}

Profesionalisme adalah tigkat penguasaan dan pelaksanaan terhadap tiga hal yaitu knowledge, skill, dan character (Novin and Trucker dalam Wulansari, 2008). Seorang yang profesional akan memiliki tingkat tertentu pada ketiga bidang.

\section{Motivasi Belajar}

Menurut Clayton Alderfer dalam Nashar (2004:42) "Motivasi belajar adalah kecenderungan siswa dalam melakukan kegiatan belajar yang didorong oleh hasrat untuk mencapai prestasi atau hasil belajar sebaik mungkin". 


\section{Pengembangan Hipotesis}

Pengaruh Kompetensi Pedagogik Dosen Akuntansi Terhadap Motivasi Belajar

Menurut penjelasan Undang-Undang RI No.14 Tahun 2005 Tentang Guru dan Dosen, yang dimaksud kompetensi pedagogik adalah kemampuan mengelola pembelajaran peserta didik. Seorang dosen mengelola pembelajaran yang baik dan menarik misalnya menggunakan strategi pembelajaran yang aktif dan menyenangkan sehingga mahasiswa akan merasa senang dan tidak merasa bosan sehingga mahasiswa akan termotivasi dengan mata pelajaran yang disampaikan. Dari pemaparan diatas maka dapat disimpulkan, bahwa terdapat hubungan positif antara kompetensi pedagogik dosen dengan motivasi belajar mahasiswa.

\section{H1 : Kompetensi Pedagogik Dosen Akuntansi Berpengaruh Positif terhadap Motivasi Belajar.}

\section{Pengaruh Profesionalisme Dosen Akuntansi Terhadap Motivasi Belajar}

Dosen dengan kewenangannya utama mengajar berhadapan langsung dengan para mahasiswa dalam arena proses belajar mengajar. Dalam interaksi edukatif diharapkan mahasiswa memperoleh apa yang diharapkan. Untuk mencapai hal tersebut maka dosen memegang peranan penting sehingga dibutuhkan kemampuan dan profesionalisme. Sementara hasil penelitian yang dilakukan oleh Nanian Mashudi, Ika Adita Silviandari, Ratri Nurwanti (2014), dengan judul Hubungan Antara Persepsi Terhadap Kompetensi Profesional Dosen Dengan Motivasi Belajar Mahasiswa menunjukkan bahwa adanya hubungan yang positif antara persepsi terhadap kompetensi profesional dosen dengan motivasi belajar mahasiswa Program Studi Psikologi Universitas Brawijaya dari nilai koefisien korelasi variabel bebas dan terikat, didapatkan $R$ Squared sebesar 0,729.

\section{H2: Profesionalisme Dosen Akuntansi Berpengaruh Positif terhadap Motivasi Belajar.}




\section{Model Penelitian}

Model penelitian dengan judul pengaruh kompetensi pedagogik dosen akuntansi terhadap motivasi belajar dapat dilihat pada gambar 1.1 dibawah ini.

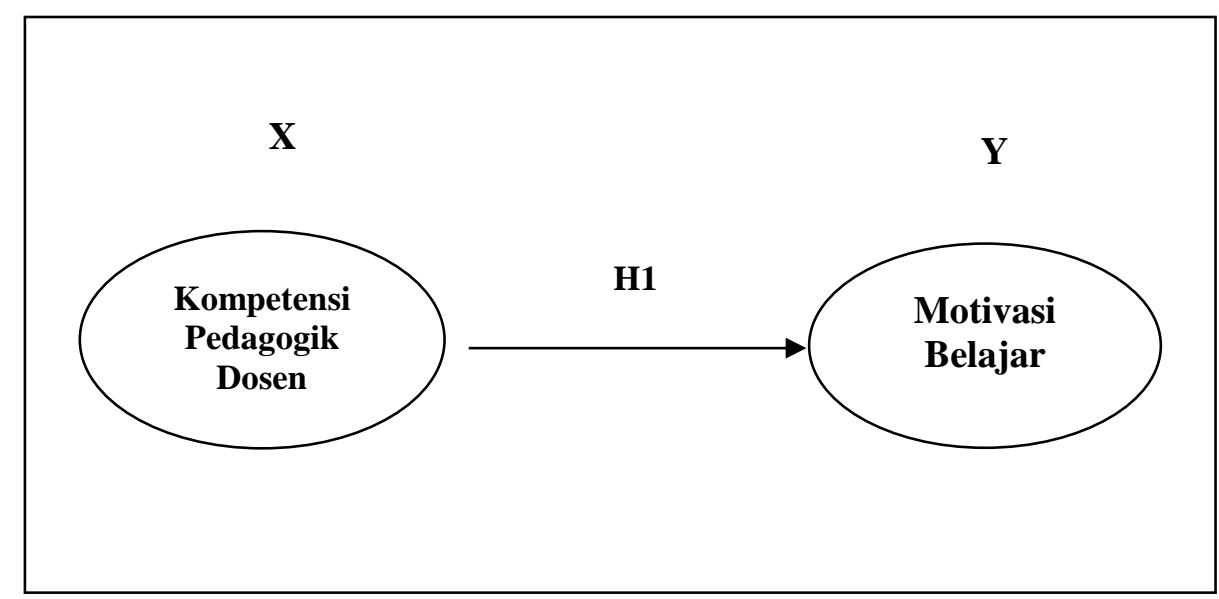

Gambar 2.1

Model Penelitian

Keterangan:

$\mathrm{H} 1=$ Hubungan $\mathrm{X} 1$ dengan $\mathrm{Y}$

\section{METODE PENELITIAN DAN PEMBAHASAN}

\section{METODE PENELITIAN}

Desain yang digunakan dalam penelitian ini adalah desain hubungan sebab akibat / Kausalitas yang menganalisis pengaruh variabel satu terhadap variabel lain. Penelitian ini bertujuan untuk menganalisis Pengaruh Kompetensi Pedagogik Dosen Akuntansi Terhadap Motivasi Belajar Mahasiswa Akuntansi (Studi Tentang Persepsi Mahasiswa Akuntansi di Universitas Pamulang Akademik 2015/2016).

Penelitian ini dilakukan di UNIVERSITAS PAMULANG yang beralamat di Jln. Jalan Surya kencana No 1 Pamulang, Kota Tangerang Selatan Provinsi Banten, Kota Tangerang - Prop. Banten - Indonesia kodepos 15417. Penelitian ini dilaksanakan pada 1 Agustus sampai 31 Agustus 2016. 
Pengumpulan data menggunakan metode survei yang dilakukan dengan cara penyebaran kuesioner kepada para mahasiswa akuntansi dengan pengukuran yang digunakan adalah menggunakan skala likert. Populasi dalam penelitian adalah Mahasiswa Program Studi Akuntansi S1 reguler B / kelas malam, mahasiswa yang sudah mengampu mata kuliah auditing 2 yaitu mahasiswa semester 8 sebanyak 294 orang. Menurut Suharsimi (2006:131) menyatakan bahwa "sampel adalah sebagian wakil dari populasi”. Pengambilan sampel dalam penelitian ini menggunakan rumus Slovin dengan rumus sebagai berikut:

$$
\begin{aligned}
n= & \underline{\mathrm{N}} \\
& \left(1+\mathrm{N} \mathrm{e}^{2}\right) \\
= & \underline{294} \\
& \left(1+294 \times 0,05^{2}\right) \\
= & 169.45 \text { dibulatkan } 169
\end{aligned}
$$

Teknik sampling yang digunakan adalah Probability Sampling dengan pengambilan sampel menggunakan teknik simple random sampling dengan mengambil sampel secara acak dengan syarat populasi bersifat homogen.

\section{HASIL PENELITIAN DAN PEMBAHASAN}

\section{Hasil}

\section{Demografi Responden Berdasarkan Umur}

Proporsi responden berdasarkan umur menggambarkan tingkat pengalaman dan kedewasaan pola pikir responden, sehingga dalam penelitian ini dapat dikelompokkan menurut tingkat responden yakni umur responden dibawah 20 tahun, 20- 24 tahun, 25 - 29 tahun, di atas = 30 tahun. Hasil data mengenai identitas responden berdasarkan umur, maka umur responden yang terbesar dalam penelitian ini adalah antara 21-24 tahun yaitu sebanyak $88 \%$. Sehingga dapat dikatakan bahwa responden yang merupakan terbanyak mengisi kuesioner dan memberikan pendapatnya adalah yang berumur antara 21-24 tahun 


\section{Demografi Responden Berdasarkan Jenis Kelamin}

Demografi responden dalam penelitian ini adalah pengelompokkan responden berdasarkan jenis kelamin (gender). Dari hasil perhitungan data proporsi demografi responden yang berjenis kelamin wanita lebih besar yakni sebanyak $72,2 \%$ jika dibandingkan dengan pria yang hanya $27,8 \%$.

\section{Deskriptif Statistik}

Deskriptif data penelitian in dapat dilihat dari rata-rata (mean), nilai minimum, nilai maksimum. Untuk memberikan gambaran mengenai variabelvariabel penelitian.

Tabel 4.1

Deskripsi Statistik Variabel Penelitian

\begin{tabular}{|c|c|c|c|c|c|c|}
\hline Variabel Penelitian & N & Min & Max & Mean & Mo & Me \\
\hline $\begin{array}{c}\text { Kompetensi Pedagogik Dosen } \\
\text { Akuntansi }\end{array}$ & 169 & 10 & 36 & 26,25 & 25 & 25 \\
\hline $\begin{array}{c}\text { Kompetensi Profesionalisme } \\
\text { Dosen Akuntansi }\end{array}$ & 169 & 14 & 36 & 27,97 & 27 & 27 \\
\hline Motivasi Belajar & 169 & 13 & 36 & 29,62 & 27 & 30 \\
\hline
\end{tabular}

Data Yang Diolah 2016

Tabel 4.1 menunjukkan nilai rata-rata secara keseluruhan dari masingmasing variabel dengan banyak responden 169. Variabel Kompetensi pedagogik dosen akuntansi memiliki rata-rata sebesar 26,25 dan untuk variabel preofesionalisme dosen akuntansi rata - rata 27,97 sementara untuk variabel motivasi belajar memiliki rata-rata 29,62. 


\section{UJI KUALITAS DATA}

\section{Uji Validitas Data}

Berikut adalah hasil pengujian validitas data

Tabel 4.2

Hasil Pengujian Validitas Pengaruh Kompetensi Pedagogik Dosen Akuntansi dan Profesionalisme Dosen Akuntansi Terhadap Motivasi Belajar

\begin{tabular}{|c|c|c|c|c|}
\hline Variabel & Kode Pernyataan & $\mathrm{r}_{\text {hit }}$ & $\mathrm{r}_{\text {tabel }}$ & Ket \\
\hline $\begin{array}{c}\text { Kompetensi Pedagogik } \\
\text { Dosen Akuntansi }\end{array}$ & $\begin{array}{c}\text { P1,P2,P3,P4,P5 } \\
\text { P6,P7,P8,P9 }\end{array}$ & $\begin{array}{c}0,836,0,783,0,783,0,774,0,368, \\
0,521,0,892,0,368,0,609\end{array}$ & 0,361 & Valid \\
\hline $\begin{array}{c}\text { Profesionalisme Dosen } \\
\text { Akuntansi }\end{array}$ & $\begin{array}{c}\text { P10, P11, P12, } \\
\text { P13, P14, P15, } \\
\text { P16, P17, P18 }\end{array}$ & $\begin{array}{c}0,669,0,692,0,373,0,501,0,660, \\
0,525,0,462,0,454,0,865\end{array}$ & 0,361 & Valid \\
\hline \multirow{2}{*}{ Motivasi Belajar } & $\begin{array}{c}\text { P19, P20, P21, } \\
\text { P22, P23, P24, } \\
\text { P25, P26, P27 }\end{array}$ & $\begin{array}{c}0,516,0,606,0,543,0,727,0,573, \\
0,485,0,679,0,654,0,742\end{array}$ & 0,361 & Valid \\
\hline
\end{tabular}

Berdasarkan tabel 1.2 yakni hasil olahan data mengenai pengujian validitas, menunjukkan bahwa untuk dari semua pernyataan dari masing - masing variabel sudah valid karena memiliki nilai korelasi di atas 0,361.

\section{Uji Reliabilitas Data}

Hasil olahan data mengenai reliabilitas data instrumen penelitian kompetensi pedagogik dosen akuntansi terhadap motivasi belajar adalah sebagai berikut yang terdapat dalam tabel 3 dibawah ini:

Tabel 4.3

Hasil Uji Reliabilitas Data Instrumen Penelitian Kompetensi Pedagogik Dosen Akuntansi dan Profesionalisme Dosen Akuntansi Terhadap Motivasi Belajar

\begin{tabular}{|l|c|c|c|}
\hline \multicolumn{1}{|c|}{ Variabel } & $\begin{array}{c}\text { Cronbach's } \\
\text { Alpha }\end{array}$ & $\begin{array}{c}\text { Cronbach's } \\
\text { Alpha Standar }\end{array}$ & Keterangan \\
\hline X1 Kompetensi Pedagogik & 0.843 & 0.60 & Reliabel \\
X2 Kompetensi Profesionalisme & 0.849 & 0.60 & Reliabel \\
Y Motivasi Belajar & 0.775 & 0.60 & Reliabel \\
\hline
\end{tabular}

Data diolah dengan spss v. 23 
Berdasarkan tabel 1.3 yakni hasil pengolahan data mengenai reliabilitas, yang menunjukkan bahwa semua item pernyataan yang diajukan sudah reliabel atau handal karena memiliki nilai cronbach's alpha diatas dari 0,60.

\section{UJI ASUMSI KLASIK}

\section{Uji Normalitas Data}

Uji normalitas dilakukan dengan melihat gambar grafik Normal P-P Plot, dimana terjadinya gejala tersebut dideteksi dengan melihat titik-titik yang mengikuti arah garis linier dari kiribawah ke kanan atas. Bila titik-titik mengikuti arah garis linier berarti terjadi adanya gejala normalitas.

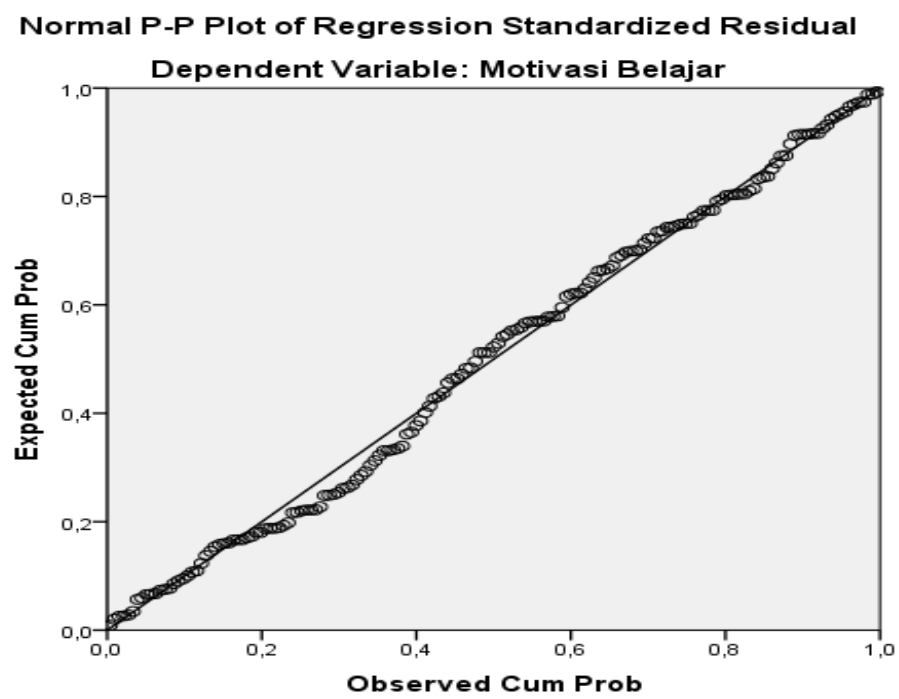

Gambar 4.1

P-Plot

\section{Uji Multikolinieritas}

Pada tabel dibawah ini menunjukkan bahwa nilai VIF umumnya berada disekitar 1 dan mempunyai angka tolerance tidak melebihi 1 , sehingga model regresi dapat dikatakan bebas multikolinieritas. Rangkuman uji multikolinieritas dalam penelitian ini dapat dilihat pada tabel 1.4 dibawah ini : 
Tabel 4.4

UJI MULTIKOLINIERITAS

\begin{tabular}{|c|c|c|}
\hline \multirow[b]{2}{*}{ Model } & \multicolumn{2}{|c|}{ Collinearity Statistics } \\
\hline & Tolerance & VIF \\
\hline 1 (Constant) & & \\
\hline $\begin{array}{c}\text { Kompetensi Pedagogik Dosen } \\
\text { Akuntansi }\end{array}$ & ,673 & 1,485 \\
\hline $\begin{array}{c}\text { Kompetensi Profesionalisme Dosen } \\
\text { Akuntansi }\end{array}$ & 673 & 1,485 \\
\hline
\end{tabular}

a.Dependent Variable: Motivasi Belajar

Sumber : Hasil Pengolahan SPSS V. 23

Berdasarkan gambar tersebut, memperlihatkan tidak ada pola yang jelas, serta titik-titik menyebar di atas dan di bawah angka 0 pada sumbu Y, maka tidak terjadi heterokedastisitas.

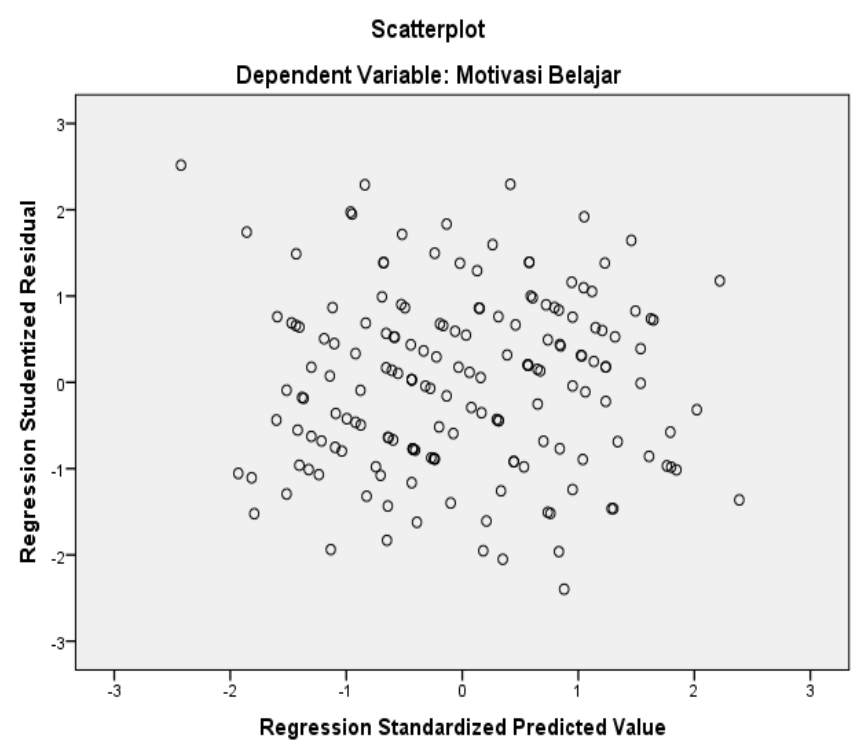

Uji Heterokedastisitas

Gambar 1.3

Analisis Regresi Berganda 
Tabel 4.5

\begin{tabular}{|rl|r|r|}
\hline \multirow{2}{*}{ Model } & \multicolumn{2}{|c|}{$\begin{array}{c}\text { Unstandardized } \\
\text { Coefficients }\end{array}$} \\
\cline { 2 - 4 } & \multicolumn{1}{|c|}{ B } & Std. Error \\
\hline 1 & $\begin{array}{l}\text { (Constant) } \\
\text { Kompetensi } \\
\text { Pedagogik } \\
\text { kompetensi } \\
\text { profesionalisme }\end{array}$ & 16,673 & 1,918 \\
&, 067 &, 073 \\
\hline
\end{tabular}

Berdasarkan pengolahan data hasil kuesioner dengan menggunakan komputerisasi program SPSS versi 23 diperoleh hasil seperti pada tabel 1.5. Bentuk persamaan regresi linier sederhana yang digunakan dalam penelitian ini adalah : $\mathrm{Y}=16.773+0.067 \mathrm{X} 1+0.397 \mathrm{X} 2+\mathrm{e}$

Persamaan regresi di atas dapat dijelaskan sebagai berikut :

$\mathrm{b}_{1}=0.067$ menunjukkan bahwa kompetensi pedagogik dosen akuntansi ditingkatkan sebesar satu satuan maka dapat diikuti oleh motivasi belajar.

$\mathrm{b}_{2}=0.397$ menunjukkan bahwa jika profesionalisme dosen akuntansi ditingkatkan sebesar satu satuan maka dapat diikuti oleh motivasi belajar.

\section{Hasil dan Pembahasan Uji Hipotesis}

\section{Analisis Koefisien Determinasi $\left(\mathbf{R}^{2}\right)$}

Tabel 4.6

Model Sum m ary

\begin{tabular}{|c|c|}
\hline Model & $\begin{array}{c}\text { Adjusted R } \\
\text { Square }\end{array}$ \\
\hline 1 &, 226 \\
\hline
\end{tabular}

Data diolah dari SPSS v 23

Dari Tabel 1.6 di atas dapat dilihat bahwa nilai koefisien determinasi yang diberikan variabel independen (X) kompetensi pedagogik dosen akuntansi dan profesionalisme dosen terhadap variabel dependen (Y) motivasi belajar. yang ditunjukkan oleh $\mathrm{R}$ square pada tabel 0.226 . Hal ini mengindikasi bahwa 
kompetensi pedagogik dosen akuntansi dan profesionalisme dosen secara bersama dapat menjelaskan tentang motivasi belajar sebesar $23 \%$.

\section{Hasil Uji T}

Pengujian ini dilakukan untuk mengetahui apakah variabel $\mathrm{X}$ berpengaruh positif secara parsial terhadap variabel $\mathrm{Y}$ berdasarkan hasil regresi yang ada pada tabel 1.5 Uji T dilakukan dengan membandingkan nilai $t_{\text {hitung }}$ dengan $t_{\text {tabel }}$. Dengan kriteria pengujian :

$t_{\text {hitung }} \geq t_{\text {tabel }}$, maka variabel independen secara parsial memiliki pengaruh yang signifikan terhadap variabel dependen.

$t_{\text {hitung }} \leq \mathrm{t}_{\text {tabel }}$, maka variabel independen secara parsial tidak memiliki pengaruh yang signifikan terhadap variabel dependen.

Tabel 4.7

Uji T

\begin{tabular}{|c|c|c|c|c|c|}
\hline Variabel & $t_{\text {hitung }}$ & Nilai Sig & $\mathrm{t}_{\text {tabel }}$ & Kebermaknaan & Hipotesis \\
\hline $\mathrm{X} 1$ & 0.920 & 0.359 & 1.97 & Tidak signifikan & Tidak terbukti \\
\hline $\mathrm{X} 2$ & 5.296 & 0.000 & 1.97 & Signifikan & Terbukti \\
\hline
\end{tabular}

Berdasarkan hasil pengelolan data pada table diatas dapat dijelaskan bahwa hitung untuk variabel kompetensi pedagogik dosen akuntansi sebesar 0.359 dengan nilai sig 0,359 . Dan hasil $t_{\text {hitung }}(0.920)<t_{\text {tabel }}(1.97)$. Artinya hasil pengujian atas hipotesis 1 tidak ada pengaruh yang signifikan antara kompetensi pedagogik dosen akuntansi terhadap motivasi belajar. Hasil dari mean variabel kompetensi pedagogik dosen menunjukan bahwa terdapat nilai mean yang memiliki nilai dibawah 2 yaitu di pernyataan no 1 dengan nilai 2,11 (Dosen memahami kemampuan kognitif peserta didik) dan pernyataan no 7 yaitu besarnya mean 2,26 (Dosen memiliki kemampuan dalam mengelola kelas sehingga mahasiswa selalu tertarik dalam proses belajar).

Jika dilihat dari hasil jawaban responden pernyataan no 1 dan no 7 ini menurut responden pernyataan tersebut tidak memiliki pengaruh terhadap motivasi belajar. Dari segi usia responden,dapat ditarik kesimpulan bahwa fokus 
dari responden bukanlah mencari dosen yang hanya mampu memahami kognitif mahasiswa dan bukan juga dosen yang pandai mengelola kelas hal ini dikarenakan responden sudahlah mandiri serta dewasa dalam pola pikir. Selain itu responden sudah tingkat akhir yaitu semester 8 yang tujuan kuliahnnya adalah untuk segera lulus dan menyelesaikan tugas akhirnya yaitu skripsi. Faktor lain yang dapat menyebabkan kompetensi pedagogik tidak signifkan dapat terjadi karena sebaran dosen yang mengajar di kelas reg b semester 8 malam tidak semuanya sama dengan dosen akuntansi reg a atau dengan reg c.

Sehingga hal ini dapat menghasilkan persepsi yang berbeda. Hasil pengujian hipotesis 1 dalam penelitian ini berbeda dengan penelitian yang dilakukan oleh Arif Nur Prasetyo (2015). perbedaan disebabkan karena beberapa hal diantaranya karena perbedaan kondisi waktu, tempat, sampel, teori, item pernyataan yang yang digunakan oleh peneliti sebelumnya, atau ada faktor lain yang menyebabkan hasil dari uji t untuk hipotesis 1 menjadi tidak signifikan. Dalam hipotesis 2 hasilnya menyatakan bahwa profesionalisme dosen akuntansi memiliki pengaruh positif dan signifikan hasil thitung $(5.296)>t_{\text {tabel }}$ (1.97). diperkuat dengan hasil dari Adnan Hakim (2015).

\section{Hasil Uji F}

Tabel 4.8

\begin{tabular}{|ll|l|c|}
\hline \multicolumn{3}{|c|}{ Uji F } \\
\hline 1 & Model & F & Sig. \\
\hline & $\begin{array}{l}\text { Regression } \\
\text { Residual } \\
\text { Total }\end{array}$ & 25,583 &, $000^{\mathrm{b}}$ \\
& & \\
\hline
\end{tabular}

Berdasarkan hasil diatas menunjukkan bahwa $F_{\text {hitung sebesar } 25.583 \text { atau }}$ 25,58 (pembulatan 2 angka dibelakang koma). Dengan demikian $F_{\text {hitung }}>F_{\text {tabel }}$ $(25,58>3.05)$, maka penulis menyimpulkan hipotesis yang menyatakan bahwa ada pengaruh positif dari kedua variabel $x$ (kompetensi pedagogik dosen akuntansi dan profesionalisme dosen akuntansi) terhadap variabel y (motivasi belajar) terbukti. 


\section{KESIMPULAN}

Temuan dari penelitian yang telah dilakukan peneliti didapat dari tiga variabel x (kompetensi pedagogik dosen akuntansi dan profesionalisme dosen akuntansi) yang memiliki pengaruh yang paling tinggi adalah variabel profesionalisme dosen akuntansi terhadap variabel y (motivasi belajar) dengan nilai $t_{\text {hitung }}$ sebesar (5.296). Jika dianalisa hasil jawaban tersebut sesuai dengan kebutuhan dari mahasiswa semester 8 yang sudah penjurusan sesuai dengan konsentrasi jurusan yang telah dipilih, dosen yang memiliki profesionalisme yang tinggi adalah yang sangat diharapkan mahasiswa. Maka dari itu diharapkan dari pihak dosen dan pihak Universitas Pamulang dapat meningkatkan terus profesionalisme dosennya, seperti pelatihan soft skill aplikasi program akuntansi terbaru, mengupgrade wawasan mengenai perkembangan teknologi, kursus bahasa asing, atau menghadirkan pakar - pakar keilmuan untuk menambah pengetahuan.

\section{DAFTAR PUSTAKA}

Abdurrahman bin said. (2008). Teori motivasi. diunduh 19 September 2016 dari <http://abdurrahmanbinsaid.wordpress.com/2008/10/09/teori-motivasi>.

Arikunto, Suharsimi. (2002). Prosedur penelitian suatu pendekatan praktek. Jakarta: Rineka Cipta.

Azhar Arsyad. (2006) . Media pembelajaran. Jakarta: Raja Grafindo Persada.

Dalyono, (2010). Psikologi pendidikan. Jakarta: Rineka Cipta.

Danim, Sudarwan. (2011). Pengembangan profesi guru dari pra-jabatan ke profesional. Jakarta: Kencana Praneda Media Group

Dimyati \& Mudjiono. (2009). Belajar dan pembelajaran. Jakarta: PT. Rineka Cipta

Ghozali, Imam. (2006). Aplikasi analisis multivariet dengan program SPSS. Badan Penerbit Universitas Diponegoro. Semarang

Goble, F. (1987). Mazhab ketiga: psikologi humanistik abraham maslow.

(Supratinya, Penerjemah). Yogyakarta: Kanisius. 
Hamalik, Oemar. (2012). Kurikulum dan pembelajaran. Jakarta: Bumi Aksara

Hamzah B. Uno. (2010). Orientasi baru dalam psikologi pembelajaran. Jakarta:

Bumi Aksara.

http://cp-artikel.blogspot.co.id/2014/03/konsep-dasar-pedagogik.htmldiakses

tanggal 1 agustus 2016

<http://forlap.dikti.go.id>. diakses tanggal 1 Juni 2016.

<http://psikologi.ub.ac.id/wp-content/uploads/2014/11/Jurnal_-Nanian-Massudi-

105120300111029.pdf>. diakses tanggal 3 Oktober 2016.

Ischayati, Isni. (2011). Kompetensi dosen dan fasilitas belajar terhadap motivasi belajar akuntansi keuangan menengah pada mahasiswa fkip-ums progdi pendidikan akuntansi angkatan 2008/2009. Skripsi thesis, Universitas Muhammadiyah Surakarta.

John W. Santrock. (2007). Psikologi pendidikan. (Tri Wibowo, penerjemah). Jakarta: Kencana.

Krisnandini Wahyu Pratiwi, Analisis pengaruh kematangan dan fasilitas belajar terhadap prestasi mahasiswa fakultas ekonomi, Jurnal Akuntansi, Manajemen Bisnis dan Sektor Publik, ISSN 1829 - 9857, vol. 4 no. 2 pebruari (2008): 167- 182 .

Muhammad Yaumi. (2013). Prinsip-prinsip desain pembelajaran, Jakarta: Kencana.

Novin, A.M dan Tucker, J.M. (1993). The composition of 150 hours accounting program: the public accountants point of views. Issues in Accounting Education (fall): 272-291.

Nyayu Khodijah. (2010). Orientasi baru dalam psikologi pembelajaran, Jakarta: Bumi Aksara.

Peraturan Pemerintah Nomor 19 Tahun 2005 Tentang Standar Nasional Pendidikan

Popi sopiatin. (2010). Manajemen belajar berbasis kepuasan siswa. Bogor: Ghalia 
Prasasti, Anita. (2007). Pengaruh persepsi siswa tentang kompetensi profesionalisme guru terhadap motivasi belajar siswa pada mata pelajaran akuntansi di sma negeri Probolinggo. Skripsi. Universitas Negeri Malang. Pujadi, Akro. (2007). Faktor-faktor yang mempengaruhi belajar studi kasus : Universitas Bunda Mulia. Bussines dan Jurnal Bunda Mulia, Vol 3, No 2, Sarimaya, Farida. (2009). Sertifikasi guru : apa dan bagaimana?. Bandung: CV. Yrama widya.

Santoso, Slamet. (2010). Teori-teori psikologi sosial. Bandung: Refika Aditama.

Sardiman AM. (2001). Interaksi dan motivasi belajar mengajar. Jakarta: Raja Grafindo Persada.

Sugiyono. (2004). Metode penelitian bisnis. Alfabeta: CV. Bandung

Sugiyono. (2009). Metode penelitian pendidikan (pendekatan kuantitatif. Alfabeta: CV. Bandung

Undang-undang Sisdiknas No. 20 Tahun 2003

Uno, Hamzah B. (2011a). Profesi kependidikan. Bandung: Remaja Rosdakarya.

Undang - Undang No. 14 tahun 2005 Tentang guru dan dosen

W. S. Winkel. (1987). Psikologi pengajaran. Jakarta: Gramedia. 